\title{
Carbon allocation and morphology of cherrybark oak seedlings and sprouts under three light regimes
}

\author{
Brian Roy LOcKHART*1, Emile S. GARDINER ${ }^{1}$, John D. HodGES ${ }^{2}$, Andrew W. EzELL ${ }^{2}$ \\ ${ }^{1}$ USDA Forest Service, Southern Research Station, Center for Bottomland Hardwoods Research, PO Box 227, Stoneville, MS 38776, USA \\ ${ }^{2}$ Department of Forestry, Mississippi State University, Mississippi State, MS 39762, USA
}

Keywords:

${ }^{14}$ C labeling /

oak reproduction /

Quercus pagoda (Raf.) /

carbon allocation

(Received 28 January 2008; accepted 22 August 2008)

\author{
Mots-clés : \\ marquage ${ }^{14} \mathrm{C} /$ \\ reproduction des chênes / \\ Quercus pagoda (Raf.) / \\ allocation de carbone
}

\begin{abstract}
- Continued problems in regenerating oak forests has led to a need for more basic information on oak seedling biology.

- In the present study, carbon allocation and morphology were compared between cherrybark oak (Quercus pagoda Raf.) seedlings and sprouts at 1-Lag grown in full, 47\%, and 20\% sunlight.

- Results indicated that cherrybark oak seedling carbon allocation and morphology responded plastically to light availability. In full light, roots were sinks for ${ }^{14} \mathrm{C}$, while shoots were sinks for ${ }^{14} \mathrm{C}$ under reduced light availability. Cherrybark oak sprouts exhibited similar carbon allocation patterns in response to light availability, but displayed stronger shoot sinks than seedlings when grown underreduced light availability. We also showed that young oak sprout roots are a sink for ${ }^{14} \mathrm{C}$-photosynthates. - Results from this study point to the need for a morphological index for oak sprout development so more precise comparisons in sprout development and physiology can be made with seedlings.
\end{abstract}

Résumé - Allocation de carbone et morphologie des semis et rejets de Quercus pagoda (Raf.) sous trois différents régimes d'éclairement.

- Des problèmes continus pour la régénération des forêts de chêne ont conduit à un besoin de plus d'informations de base sur la biologie des semis de chêne.

- Dans la présente étude, l'allocation de carbone et la morphologie ont été comparées entre des semis de Quercus pagoda Raf. et des rejets au stade de développement 1Lag cultivés en pleine lumière, à $47 \%$ et à $20 \%$ de lumière.

- Les résultats ont indiqué que l'allocation de carbone et la morphologie des semis de chêne ont répondu plastiquement à la disponibilité en lumière. En pleine lumière, les racines ont été des puits pour ${ }^{14} \mathrm{C}$, tandis que les pousses ont été des puits pour ${ }^{14} \mathrm{C}$ sous une disponibilité réduite de la lumière. Les rejets ont montré des modes d'allocation de carbone similaires en réponse à la disponibilité en lumière, mais ont montré des puits plus importants que les jeunes plants quand ils ont été cultivés sous un éclairement réduit. Nous avons également montré que les jeunes chênes pousses des racines sont un puits pour photosynthats ${ }^{14} \mathrm{C}$.

- Les résultats de cette étude soulignent le besoin d'un indice morphologique de développement des rejets de chêne de manière à pouvoir faire des comparaisons plus précises en ce qui concerne le développement des rejets et leur physiologie par rapport aux jeunes plants.

\section{INTRODUCTION}

Oak (Quercus spp.) is among the most prevalent genera of trees in temperate broadleaf forests (Johnson et al., 2002). The many species of oak provide many ecological benefits including habitat and mast for a diversity of wildlife species, and are a major component of wood products in the global market. Unfortunately, sustainability of the oak resource in tem- perate regions is jeopardized by problems with stand regeneration (Lorimer, 1993). Natural regeneration problems in oak stands range from adequate and timely acorn production (Cecich, 1993), successful seedling establishment (Watt, 1979), seedling growth and competitiveness (Sander, 1972), and seedling response to release (Sander, 1972). Problems have also been noted in artificial regeneration efforts to establish oak seedlings through direct seeding acorns or planting bareroot seedlings (Gardiner et al., 2002).

\footnotetext{
* Corresponding author: blockhart@fs.fed.us
} 
A key element needed to solve the oak regeneration problem is additional knowledge of basic seedling biology, including environmental requirements for seedling survival and development (Crow, 1988; Dickson et al., 2000a). Oak seedlings exhibit a stress-tolerant growth strategy whereby carbon acquisition and allocation are determined by resource availability and environmental conditions (Collet et al., 1998; Kolb et al., 1990). Plasticity in oak seedlings relative to other species enables them to respond to a wide range of environmental conditions. Under favorable conditions, oak seedlings can exhibit rapid height growth by producing multiple flushes which increase leaf area and subsequent carbon acquisition in a positive feedback loop (Chaar et al., 1997; Collet and Frochot, 1996; Crow, 1988; Dickson et al., 2000a, 2000b; Hanson et al., 1986; Reich et al., 1980). Under unfavorable conditions, oak seedlings allocate carbon to specific tissues to tolerate or avoid stress (Abrams, 1990; Beon and Bartsch, 2003; Gardiner and Hodges, 1998; Kolb et al., 1990; van Hees, 1997; Welander and Ottosson, 1998; Ziegenhagen and Kausch, 1995). Oak seedlings also can readily sprout from dormant buds located at the base of the stem following disturbances such as fire and harvesting (Sander, 1972). These varied growth strategies allow oak seedlings to compete successfully on poor quality sites but place them at a competitive disadvantage to other species on high quality sites. An understanding of how oak reproduction responds to various environmental conditions will provide information needed to develop silvicultural practices that improve regeneration success (Collet et al., 1998).

The objective of this research was to increase our knowledge of carbon allocation and morphology of cherrybark oak (Q. pagoda Raf.) seedlings and sprouts raised under different light regimes. Our hypotheses were (1) oak seedlings and sprouts would differentiate carbon distribution between roots and shoots based on light availability levels, and (2) carbon allocation between oak seedlings and sprouts would not differ between plants of a similar morphological development stage within a given light availability level.

\section{MATERIALS AND METHODS}

\subsection{Study site description}

The study site was located at the Blackjack Research Facility near Mississippi State University, Starkville, Mississippi, USA $\left(33.3^{\circ} \mathrm{N}\right.$, $\left.88.5^{\circ} \mathrm{W}\right)$. Climate at the site is humid subtropical, characterized by temperate winters; long, hot summers; and rainfall evenly distributed throughout the year, although periodic summer droughts occur (Mississippi State Climate Office, http://www.msstate.edu/dept/ GeoSciences/climate/). Mean annual precipitation is $1354 \mathrm{~mm}$ and mean annual temperatures range from $28.1{ }^{\circ} \mathrm{C}$ in July to $5.3{ }^{\circ} \mathrm{C}$ in January.

\subsection{Plant material}

Two-year-old bare-root cherrybark oak seedlings were obtained from Delta View Nursery, Leland, MS, USA in January 1989 and stored in a walk-in refrigerator at $5{ }^{\circ} \mathrm{C}$ for one month. In February 1989, 111 unbranched seedlings selected for uniform height were planted in $15.1 \mathrm{~L}$ black plastic pots filled with a 1:1 volume mixture of sphagnum peat moss and sandy-loam soil. Soil $\mathrm{pH}$ was adjusted to 5.3 with lime. After potting, seedlings were placed in a shade house where they received $20 \%$ light availability for the 1989 growing season. Light availability was controlled using designated Saran shade cloth. The $20 \%$ light level is indicative of levels found under a forest overstory canopy with moderate midstory canopy competition (Jenkins and Chambers, 1989). Seedlings were watered as needed to maintain soil moisture near field capacity.

\subsection{Treatments and ${ }^{14} \mathrm{C}$ labeling}

Seedlings were randomly divided into 3 groups in February 1990. Each group was assigned a light availability treatment consisting of 100,47 , or $20 \%$ of full sunlight. The 100 and $47 \%$ treatments were designed as a release from $20 \%$ light that plants were grown under during 1989. One-half of the seedlings assigned to each light level were clipped at $3 \mathrm{~cm}$ above the groundline to initiate sprout development.

All plants were maintained and developed under their assigned light availability treatments through June 1990. At this time, plants were selected for ${ }^{14} \mathrm{C}$ labeling, and measured for various morphological variables. To minimize variability between seedlings, plants were randomly selected from a subset of plants in the 1-Lag development stage (Hanson et al., 1986). 1-Lag refers to the oak seedling developmental stage in which first flush stem and leaf growth have completed. The shoot is in an apparent "resting" stage until the initiation of a second flush of growth. Height $(\mathrm{cm})$, primary first flush length $(\mathrm{cm})$, number of leaves, and number of sprouts on clipped seedlings were recorded. Stem diameter was measured at $2.5 \mathrm{~cm}$ above the soil surface for seedlings, and at $2.5 \mathrm{~cm}$ above the sprout origin for sprouts.

Labeling methods followed those used by Isebrands and Nelson (1983) and Lockhart et al. (2003). A plastic cup and tygon tubing were taped to the primary first flush stem of each cherrybark oak seedling. $\mathrm{A} \mathrm{CO}_{2}$-impermeable mylar plastic bag was then placed over the primary F1 stem and part of the main older stem and doublefastened at the lower end with a twist-tie and cellophane tape. In several cases, additional first flushes on intact seedlings were included with the primary first flush due to their close proximity to the primary first flush stem and leaves. In cases of multiple sprouts from clipped seedlings, the mylar bag was placed only over the tallest seedling sprout. The remaining sprouts were not labeled. A handheld air pump was used to fill the bag with ambient air. Five $\mathrm{mL}$ of $5.55 \mathrm{MBq}(150 \mu \mathrm{Ci}) \mathrm{Na}_{2} \mathrm{H}^{14} \mathrm{CO}_{3}$ was then injected into the cup through the mylar bag with a syringe. Using a second syringe, $5 \mathrm{~mL}$ of $20 \%$ lactic acid was added to the cup and the syringe hole was immediately sealed with cellophane tape. The reaction of sodium bicarbonate with lactic acid produced ${ }^{14} \mathrm{CO}_{2}$ which seedlings were allowed to fix for $30 \mathrm{~min}$. During this time, ambient air was periodically introduced. After fixation, the remaining liquid was withdrawn using the second syringe and the bag opened.

All labeling was conducted during a 2-week period under clear skies and warm days in June 1990. Four plants in each light availability and clipping treatment were labeled in their respective light treatments during 1-Lag. Only 3 seedling sprouts were available for labeling in the $20 \%$ light treatment $(n=27)$. The small sample size is common for experiments using ${ }^{14} \mathrm{C}$ tracers due to expected low 
Table I. Morphological characteristics of cherrybark oak seedlings and sprouts at the time of labeling with ${ }^{14} \mathrm{C}$. Abbreviation: F1=first flush. Values are means $\pm 1 \mathrm{SE}$.

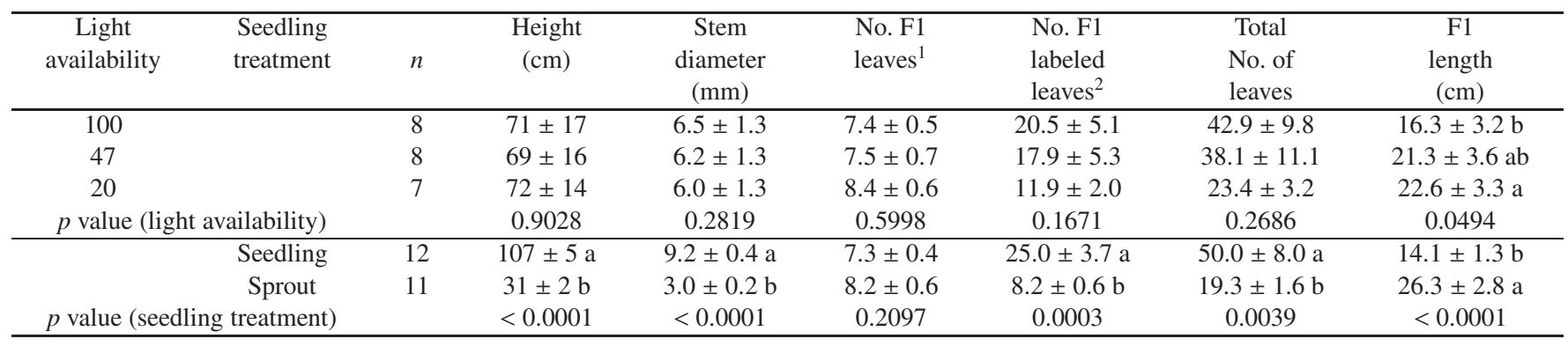

${ }^{1}$ Number of F1 leaves is only for the primary terminal stem and does not include branch F1 flushes.

${ }^{2}$ Calculated for seedlings based on the proportion of labeled leaf dry mass/total leaf dry mass multiplied by the total number of leaves.

${ }^{3}$ Values followed by different letters within a column by treatment are significantly different $(p \leq 0.05)$.

variability within treatments and expense in utilizing radioactive materials (Dickson et al., 2000a; Isebrands and Dickson, 1991).

\subsection{Plant harvesting}

Plants were excavated from pots and dissected into biomass components $48 \mathrm{~h}$ after labeling. The 48 -h period was considered sufficient time for mobile ${ }^{14} \mathrm{C}$-assimilates to be translocated from source leaves (Isebrands and Dickson, 1991). The shoot of each plant was separated into the following tissues: (1) labeled primary first-flush (F1) leaves, (2) labeled primary F1 stem, (3) other labeled branch F1 leaves, (4) other labeled branch F1 stems, (5) main stem, (6) unlabeled branch F1 leaves, (7) unlabeled branch F1 stems, (8) unlabeled branch older stems, (9) stool, or sprout stump, (10) unlabeled sprout F1 leaves, and (11) unlabeled sprout F1 stems. Other labeled branch F1 leaves and their associated stems were from seedlings where these flushes were growing from the same terminal position as the primary F1 flush; therefore, they were enclosed in the mylar bag along with the primary F1 flush during labeling. Root systems were separated into taproot and lateral root tissues. Taproots were defined as the portion of the root system intact during planting since few lateral roots were present on the seedlings at the time of planting. Seedlings obtained from the nursery had been laterally root pruned and undercut while in the nursery bed. The few lateral roots remaining were removed prior to planting so all lateral roots at F1 harvest represented new root growth except for taproot girth expansion. Each tissue was placed in individual plastic bags and transported in an ice cooler to the laboratory for cold storage at $-2{ }^{\circ} \mathrm{C}$.

To process the biomass samples, tissues were oven dried at $105^{\circ} \mathrm{C}$ for $48 \mathrm{~h}$. Dried samples were weighed, then 1 to 3 subsamples were taken from each tissue (about 0.10 to $0.20 \mathrm{~g}$ for F1 leaves and stems, 0.15 to $0.50 \mathrm{~g}$ for roots, and 0.30 to $0.60 \mathrm{~g}$ for older woody material) and oxidized at $900{ }^{\circ} \mathrm{C}$ using a Harvey Model OX-600 Biological Oxidizer ${ }^{\circledR}$. The radioactivity of the oxidized subsamples was counted 5 times using a Packard ${ }^{\circledR}$ liquid scintillation counter.

\subsection{Statistical analyses}

Methods used to calculate total ${ }^{14} \mathrm{C}$ in plant tissues follow Lockhart et al. (2003). Unlabeled branch tissues (older stem, F1 leaves, and F1 stems) on intact seedlings and unlabeled F1 leaves and F1 stems on multiple sprouts were combined due to their low radioactivity. Tissue ${ }^{14} \mathrm{C}$ were summed to obtain total ${ }^{14} \mathrm{C}$ for plants. Percent recovered ${ }^{14} \mathrm{C}$ was calculated by dividing the plant ${ }^{14} \mathrm{C}$ content by the difference resulting from the $5.55 \mathrm{Mbq}$ of radioactive $\mathrm{NaH}^{14} \mathrm{CO}_{3}$ used in labeling minus the ${ }^{14} \mathrm{C}$ remaining in the cup after fixation. Percent exported ${ }^{14} \mathrm{C}$ was calculated as the difference between source leaf ${ }^{14} \mathrm{C}$ content and plant ${ }^{14} \mathrm{C}$ content.

We compared morphological characteristics, recovered ${ }^{14} \mathrm{C}$, and exported ${ }^{14} \mathrm{C}$ between seedling and sprouts using a split-plot design with PROC MIXED in PC-SAS (SAS, 1985) for light availability (whole plot) and seedling treatments (split plot; seedlings compared to sprouts). Percent data were transformed using the arcsine function. Least square means was used for mean separation when the whole plot or seedling treatment effects were significant. Mean separation as described in Peterson (1985) was used to separate means when a significant interaction between light availability and seedling treatment occurred (level of significance was alpha $\leq 0.05$ ).

\section{RESULTS}

\subsection{Morphology}

Few morphological differences existed in cherrybark oak plants among the three light levels (Tab. I). The primary F1 stem was shorter for plants in full sunlight compared to plants in $20 \%$ light. Leaf numbers on the primary F1 flush did not differ between treatments though we observed that leaves were distributed regularly along the F1 stem for plants in full and $47 \%$ light. Leaves on plants in $20 \%$ light were clustered near the top of the flush - lower nodes along the F1 stem did not produce leaves. In general, leaves occurred more often on a given node with increasing light levels.

Stem height was $245 \%$ and diameter was $207 \%$ greater for cherrybark oak seedlings compared to sprouts following the 1Lag stage of seedling development (Tab. I). These results were expected because sprout shoots were in their first growing season after clipping (3 months growth) while seedling shoots were in their fourth growing season. Yet, F1 stem lengths were greater for sprouts compared to seedlings. Cherrybark 
Table II. Dry mass (g) for tissues of cherrybark oak seedlings and sprouts grown under three light regimes. Values are means \pm SE.

\begin{tabular}{|c|c|c|c|c|c|c|}
\hline $\begin{array}{c}\text { Light } \\
\text { availability }\end{array}$ & $\begin{array}{l}\text { Seedling } \\
\text { treatment }\end{array}$ & $n$ & Roots & Shoots & Plant & $\begin{array}{c}\text { Root/shoot } \\
\text { ratio }\end{array}$ \\
\hline 100 & & 8 & $27.7 \pm 3.2$ & $26.3 \pm 7.3$ & $54.0 \pm 10.1$ & $1.5 \pm 0.2$ \\
\hline 47 & & 8 & $28.0 \pm 3.5$ & $25.7 \pm 6.9$ & $53.7 \pm 10.2$ & $1.5 \pm 0.3$ \\
\hline 20 & & 7 & $20.7 \pm 1.8$ & $21.4 \pm 5.0$ & $42.1 \pm 6.3$ & $1.4 \pm 0.4$ \\
\hline \multicolumn{2}{|c|}{$p$ value (light availability) } & & 0.2314 & 0.5167 & 0.3412 & 0.9122 \\
\hline & Seedling & 12 & $30.0 \pm 2.6 \mathrm{a}^{1}$ & $38.3 \pm 4.0 \mathrm{a}$ & $68.3 \pm 6.3 \mathrm{a}$ & $0.8 \pm 0.1 \mathrm{~b}$ \\
\hline
\end{tabular}

${ }^{1}$ Values followed by different letters within a column by light availability or seedling treatment are significantly different $(p \leq 0.05)$.

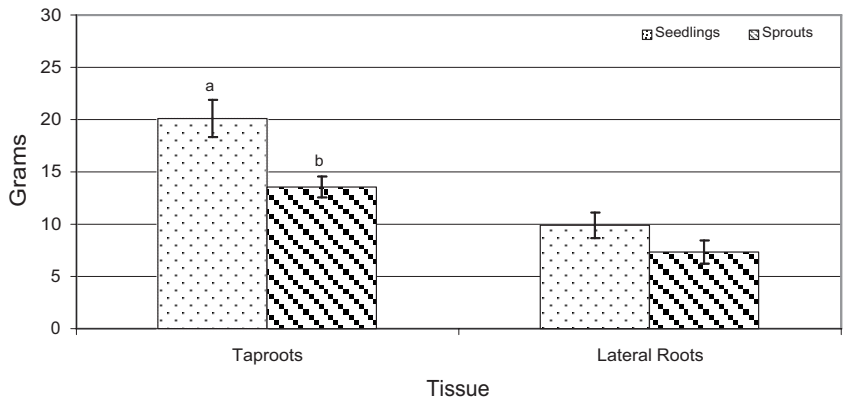

Figure 1. Taproot and lateral root dry weight $(\mathrm{g})$ between cherrybark oak seedlings and sprouts. Bars with different letters in the taproot section are significantly different $p \leq 0.05$. Lines denote $\pm 1 \mathrm{SE}$.

oak seedlings did have a greater number of total leaves compared to sprouts because of branches present on these older shoots. In this study, sprouts did not develop branches, but most developed multiple stems $($ mean $=2.9$ stems per stool with a range of 1 to 5 stems per stool).

\subsection{Dry mass}

In general, cherrybark oak seedlings were $122 \%$ larger in dry mass than sprouts. Root dry mass for seedlings was $43 \%$ greater than that of sprouts while seedling shoot mass was 295\% than sprout shoot mass (Tab. II). Differences were not found for dry mass accumulation between light availability treatments. As expected, the root/shoot ratio of sprouts was greater than that of seedlings (Tab. II). The seedling root/shoot ratio was nearly equal $(1: 1)$ while sprout roots showed over twice the biomass of sprout shoots at 1-Lag.

Among plant tissues (taproots, lateral roots, labeled F1 leaves and stems), no differences were found in dry mass accumulation between light availability treatments ( $p$ values ranged from 0.1195 to 0.5520 ). Seedling taproots accumulated $48 \%$ more dry mass than sprouts ( $p=0.0055)$, but no difference occurred in lateral root dry mass between seedlings and sprouts ( $p=0.0550 ;$ Fig. 1$)$. No differences in dry mass were found among the main stem and unlabeled branch tissues in seedlings among the light treatments $(p=0.5745$ and 0.4437 , respectively).

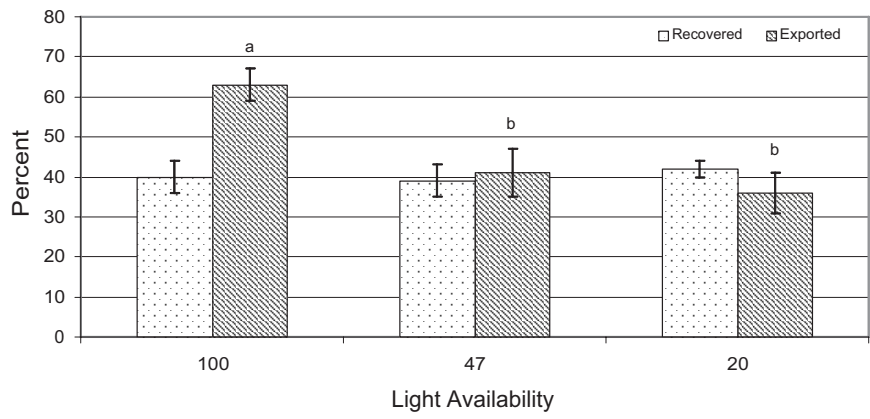

Figure 2. Recovered and exported ${ }^{14} \mathrm{C}(\%)$ in cherrybark oak seedlings and sprout under 3 levels of light availability. Bars with different letters within the exported section are significantly different at $p \leq 0.05$. Lines denote $\pm 1 \mathrm{SE}$.

\section{3. ${ }^{14} \mathrm{C}$ recovery and export}

The ${ }^{14} \mathrm{C}$ recovered from cherrybark oak seedlings and sprouts averaged $40 \%$ of the ${ }^{14} \mathrm{C}$ present in the $\mathrm{NaH}^{14} \mathrm{CO}_{3}$ solution. No differences were found in recovered ${ }^{14} \mathrm{C}$ between light availability ( $p=0.8832$; Fig. 2$)$, or seedling treatment $(p=0.2009$; Fig. 3$) .{ }^{14} \mathrm{C}$ exported from cherrybark oak source leaves ranged from $68 \%(\mathrm{SE} \pm 4)$ for seedlings in full sunlight to $27 \%(\mathrm{SE} \pm 5$ ) for sprouts in $20 \%$ light availability. A greater percentage of fixed ${ }^{14} \mathrm{C}$ was exported from source leaves in full sunlight compared to shaded seedlings and sprouts ( $p=0.0050$; Fig. 2). Further, more fixed ${ }^{14} \mathrm{C}$ was exported from source seedling leaves compared to source sprout leaves ( $p=0.0008$; Fig. 3 ).

\section{4. ${ }^{14} \mathrm{C}$ distribution}

A lower percentage of ${ }^{14} \mathrm{C}$ was found in roots (30\%) compared to shoots (70\%) in cherrybark oak seedlings and sprouts during their respective 1-Lag stage of development. Roots of plants grown under reduced light conditions had lower percentages of ${ }^{14} \mathrm{C}$ than plants grown in full light, especially for sprout roots (Tab. III). A consistent pattern exists where less ${ }^{14} \mathrm{C}$ was found in the roots (a likewise increase in ${ }^{14} \mathrm{C}$ in shoots) with decreasing light. 
Table III. ${ }^{14} \mathrm{C}$ distribution $(\%)$ for recovered labeled photosynthates for tissues of cherrybark oak seedlings and sprouts under three light regimes. Values are means $\pm \mathrm{SE}$.

\begin{tabular}{|c|c|c|c|c|c|c|c|c|}
\hline $\begin{array}{c}\text { Light } \\
\text { availability }\end{array}$ & $\begin{array}{l}\text { Seedling } \\
\text { treatment }\end{array}$ & $n$ & Roots & Shoots & Taproots & $\begin{array}{c}\text { Lateral } \\
\text { roots }\end{array}$ & $\begin{array}{c}\text { First-Flush } \\
\text { leaves }\end{array}$ & $\begin{array}{c}\text { First-Flush } \\
\text { stems }\end{array}$ \\
\hline \multirow[t]{2}{*}{100} & Seedling & 4 & $43 \pm 7 \mathrm{ab}^{1}$ & $57 \pm 7 b$ & $21 \pm 3 a b$ & $22 \pm 6$ & $32 \pm 4$ & $4 \pm 1$ \\
\hline & Sprout & 4 & $46 \pm 9 \mathrm{a}$ & $54 \pm 9 b$ & $27 \pm 3 \mathrm{a}$ & $19 \pm 6$ & $42 \pm 6$ & $9 \pm 2$ \\
\hline 47 & Sprout & 4 & $14 \pm 5 c$ & $86 \pm 5 a$ & $10 \pm 5 \mathrm{~cd}$ & $4 \pm 1$ & $73 \pm 5$ & $11 \pm 2$ \\
\hline \multirow[t]{2}{*}{20} & Seedling & 4 & $25 \pm 4 \mathrm{bc}$ & $75 \pm 4 \mathrm{ab}$ & $16 \pm 3 \mathrm{bcd}$ & $9 \pm 2$ & $58 \pm 4$ & $4 \pm<1$ \\
\hline & Sprout & 3 & $14 \pm 6 c$ & $86 \pm 6 a$ & $7 \pm 3 \mathrm{~d}$ & $7 \pm 3$ & $73 \pm 9$ & $9 \pm 2$ \\
\hline \multicolumn{2}{|l|}{47} & 8 & $26 \pm 5$ & $75 \pm 5$ & $15 \pm 3$ & $11 \pm 3$ & $59 \pm 6 a$ & $8 \pm 2$ \\
\hline \multicolumn{2}{|l|}{20} & 7 & $20 \pm 4$ & $80 \pm 4$ & $12 \pm 3$ & $8 \pm 2$ & $64 \pm 5 a$ & $6 \pm 1$ \\
\hline \multicolumn{3}{|c|}{$p$ value (light availability) } & & & & 0.0865 & 0.0074 & 0.5565 \\
\hline & Seedling & 12 & $35 \pm 3$ & $65 \pm 3$ & $19 \pm 2$ & $16 \pm 3 a$ & $45 \pm 4 b$ & $10 \pm 1 \mathrm{a}$ \\
\hline & Sprout & 11 & $25 \pm 6$ & $75 \pm 6$ & $15 \pm 3$ & $10 \pm 3 b$ & $62 \pm 6 a$ & $4 \pm 1 b$ \\
\hline
\end{tabular}

${ }^{1}$ Values followed by different letters within a column by light availability, seedling treatment, or interaction are significantly different $(p \leq 0.05)$.

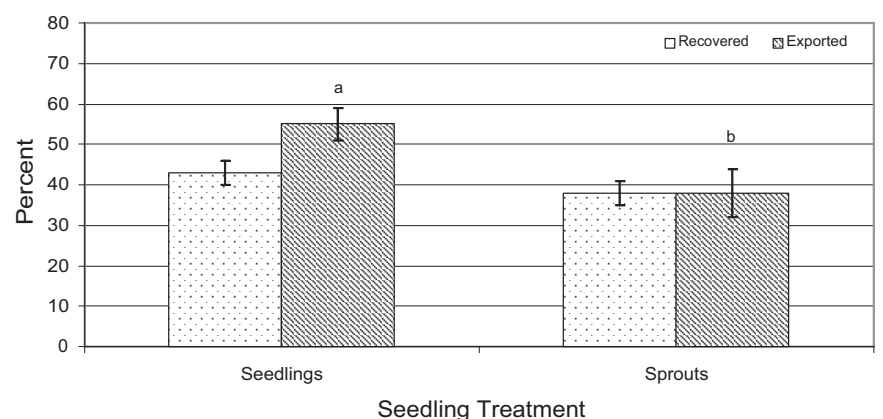

Figure 3. Recovered and exported ${ }^{14} \mathrm{C}(\%)$ in cherrybark oak seedlings and sprouts. Bars with different letters within the exported section are significantly different at $p \leq 0.05$. Lines denote \pm 1 SE.

Taproot and lateral root tissues contained $17 \%$ and $13 \%$ of fixed ${ }^{14} \mathrm{C}$, respectively. The trend of decreasing ${ }^{14} \mathrm{C}$ with decreasing light availability appears for both taproot and lateral root tissues but is only significant for taproots (Tab. III). Fiftythree percent of fixed ${ }^{14} \mathrm{C}$ was found in labeled $\mathrm{F} 1$ leaves for cherrybark oak seedlings and sprouts. A greater percentage of fixed ${ }^{14} \mathrm{C}$ remained in leaves raised under reduced light compared to those in full light (Tab. III). Labeled sprout leaves also contained more fixed ${ }^{14} \mathrm{C}$ than seedling leaves (Tab. III). A smaller percentage of ${ }^{14} \mathrm{C}$ was found in the labeled $\mathrm{F} 1$ sprout stems than seedlings (Tab. III). The main stem tissue on seedlings contained about $16 \%$ of fixed ${ }^{14} \mathrm{C}$ (data not shown). Seedlings grown under full light showed a greater percentage of fixed ${ }^{14} \mathrm{C}$ in the main stem $(21 \pm 3 \%)$ than those grown under reduced light $(13.5 \pm 1 \% ; p=0.0345)$. Unlabeled branch tissues, including older stems, F1 leaves, and associated $\mathrm{F} 1$ stems, contained $<1 \%$ of fixed ${ }^{14} \mathrm{C}$. Likewise, unlabeled sprout tissues contained low percentages of fixed ${ }^{14} \mathrm{C}$ with stools containing $2 \%$ and unlabeled sprouts from multiple sprout seedlings containing $<1 \%$ in both $\mathrm{F} 1$ leaves and stems.

\section{5. ${ }^{14} \mathrm{C}$ exported}

Cherrybark oak seedling and sprout roots contained $61 \%$ exported ${ }^{14} \mathrm{C}$ from source leaves. Roots on sprouts in full light had a greater percentage of exported ${ }^{14} \mathrm{C}$ than sprouts in shade, while sprout shoots generally had greater percentages than seedlings under reduced light (Tab. IV). Taproot and lateral root tissues contained $35 \%$ and $26 \%$, respectively, of exported ${ }^{14} \mathrm{C}$ with few differences between light availability and seedling treatments (Tab. IV). Seedling F1 stems contained relatively little exported ${ }^{14} \mathrm{C}$ while sprout $\mathrm{F} 1$ stems contained over one-third of exported ${ }^{14} \mathrm{C}$ (Tab. IV). Further, seedling and sprout F1 stems under $47 \%$ light had a greater percentage of exported ${ }^{14} \mathrm{C}$ than stems in full light (Tab. IV). The main stem tissue of intact seedlings contained $29 \%(\mathrm{SE} \pm 3$ ) of exported ${ }^{14} \mathrm{C}$ with no difference between light treatments $(p=0.2214)$. Branch tissues contained $<1 \%$ of exported ${ }^{14} \mathrm{C}$. Likewise, sprout stools, unlabeled F1 leaves and associated F1 stems contained $6 \%(\mathrm{SE} \pm 3), 2 \%(\mathrm{SE} \pm 1)$, and $1 \%(\mathrm{SE} \pm<1)$ of exported ${ }^{14} \mathrm{C}$, respectively.

\section{DISCUSSION}

Cherrybark oak seedlings and sprouts contained a high percentage of ${ }^{14} \mathrm{C}$ in roots at full sunlight compared to stems in shaded conditions. This pattern of carbon allocation to roots over shoots in high light environments reflects a plastic response in oak seedling carbon allocation that is probably driven by water stress. High light environments are typically characterized by higher air temperatures and lower relative humidity than adjacent shaded environments (Hodges, 1967). As a result, leaves in high light environments experience greater vapor pressure deficits than leaves in reduced light environments (Fitter and Hay, 1987). High vapor pressure deficits reduce stomata opening (Cowan, 1994), subsequently reducing photosynthetic rates. Though the plants in our experiment 
Table IV. ${ }^{14} \mathrm{C}$ distribution (\%) for exported labeled photosynthates from source leaves tissues of cherrybark oak seedlings and sprouts under three light regimes. Values are means $\pm \mathrm{SE}$.

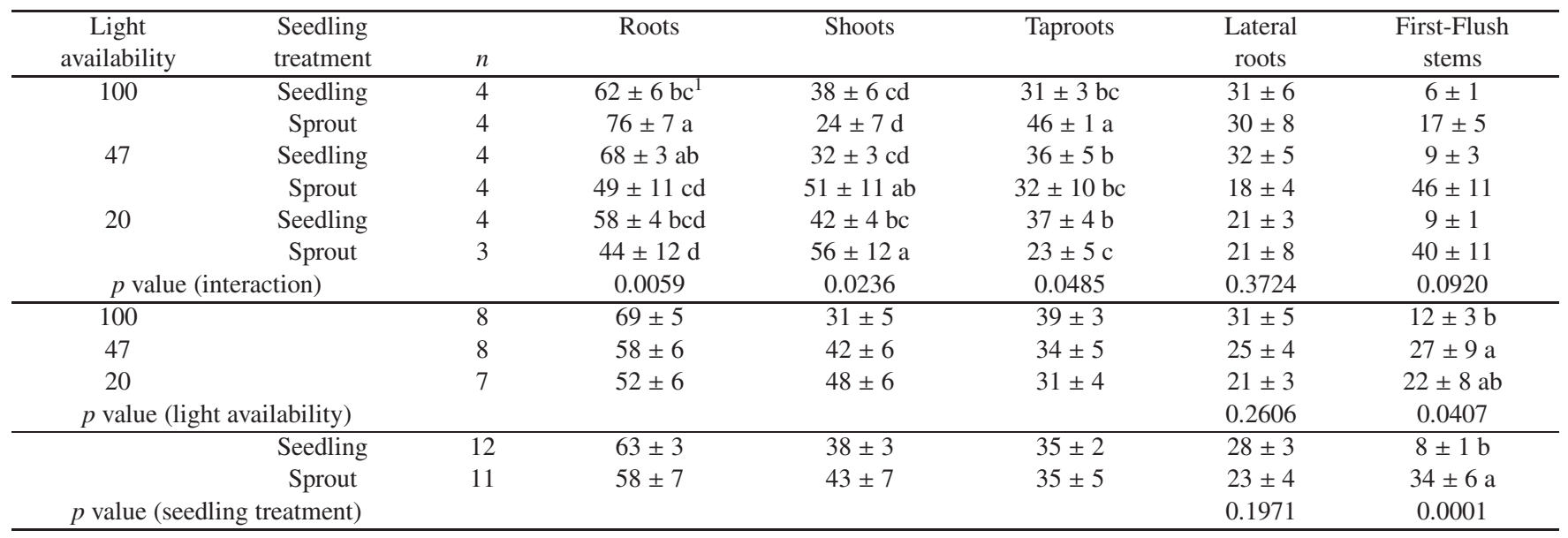

${ }^{1}$ Values followed by different letters within a column by light availability, seedling treatment, or interaction are significantly different $(p \leq 0.05)$.

were watered to field capacity on a regular basis, those growing under full light probably experienced diurnal periods of water stress which triggered the observed ${ }^{14} \mathrm{C}$ allocation response to roots. Support for this argument has been established by others who examined root/shoot ratios of other oak species established under various light environments (Gardiner and Hodges, 1998; Kolb et al., 1990; Welander and Ottosson, 1998). We hypothesize that preferential root growth in full light, based on the ${ }^{14} \mathrm{C}$ distribution pattern, is necessary to increase water acquisition for stomatal tugor, thus allowing the plant to maintain photosynthesis as vapor pressure deficits increase diurnally.

Cherrybark oak seedlings and sprouts allocated more carbon to shoot tissues as light availability decreased. Though seedling and sprout shoots were sinks for fixed ${ }^{14} \mathrm{C}$ regardless of light levels, mean shoot ${ }^{14} \mathrm{C} \%$ was higher in $20 \%$ light. Allocating more carbon to shoots is a common response in low light environments (van Hees, 1997), presumably to increase light-gathering capabilities where light is limiting. Van Hees (1997), working with pedunculate oak ( $Q$. robur L.), found that reduced light increased biomass accumulation in stems and branches through increased leaf area and specific leaf area. Working with the same species, Welander and Ottosoon (1998) found decreasing root/shoot ratios (dry weight) with decreasing light availability while Ziegenhagen and Kausch (1995) found larger leaf sizes with decreasing light. Similar morphological and biomass accumulation responses were found with other oak species (Gottschalk, 1994; Kolb et al., 1990).

Stem sprouting is a plant regeneration mechanism in response to disturbance (Bond and Midgley, 2001), and is species dependent (Kammesheidt, 1998). Quercus species are highly noted for their sprouting ability due to the large number of dormant buds that exist at the base of stems (Bourdeau, 1954). Oaks readily sprout from their base if disturbed and this sprouting ability is often used by forest resource managers to regenerate oak forests (Johnson et al., 2002). Physiologi- cally, severing oak stems to induce sprouting drastically alters the functional equilibrium between roots and shoots (Borchert, 1975). Sprouts exhibit rapid shoot growth (Kruger and Reich, 1993b; Sander, 1971), that may be supported by an abundance of root carbohydrate reserves (Tschaplinski and Blake, 1989b), increased rates of $\mathrm{CO}_{2}$ exchange (Kruger and Reich, 1993a; Tschaplinski and Blake, 1989a), increased water transport capabilities (Blake and Tschaplinski, 1986) and altered hormone relations (Taylor et al., 1982).

Cherrybark oak sprouts in our study had smaller diameters and shorter heights than seedlings, but this was due to our study design in which seedlings and sprouts were harvested in the 1-Lag development stage (Tab. I). Sprouts did have greater F1 stem lengths compared to seedlings (Tab. I), but had lower root and shoot dry mass (Tab. II). Nevertheless, sprout F1 leaves and lateral roots contained more fixed ${ }^{14} \mathrm{C}$ (Tab. III), and F1 stems contained more ${ }^{14} \mathrm{C}$ exported from source leaves (Tab. IV) than intact seedlings.

Dickson et al. (2000a; 2000b) showed that carbon allocation and partitioning in northern red oak seedlings was dependent on the stage of seedling ontogeny. During 1-lag, median source leaves allocated fixed ${ }^{14} \mathrm{C}$ basipetally to lower stem and root tissues, primarily partitioned into storage as starch. This allocation pattern shifted in response to the development of the second flush (F2). During F2 development, ${ }^{14} \mathrm{C}$ from F1 source leaves was allocated acropetally to developing F2 stems and leaves. During F2 lag, F1 source leaves again shifted carbon allocation to lower stem and roots. Therefore, source leaves in northern red oak (Q. rubra L.) seedlings, and probably seedlings for most oak species, allocate carbon based on the stage of seedling ontogeny, i.e., if the seedling was in lag or actively flushing. These patterns of carbon allocation follow general source-sink relationships in plants (Geiger, 1987; Turgeon, 1989).

In cherrybark oak sprouts, considerable ${ }^{14} \mathrm{C}$ was retained in F1 source leaves, especially for plants in low light environments (Tab. III). Dickson et al. (1990; 2000a) indicated 
that fully expanded leaves in northern red oak seedlings were still physiologically immature and the ${ }^{14} \mathrm{C}$ was utilized primarily in structural carbohydrates, in addition to sugars, starch, and proteins, as part of the leaf maturation process. The greater amount of ${ }^{14} \mathrm{C}$ retained in $\mathrm{F} 1$ sprout source leaves in reduced light (Tab. III), combined with the large percent of exported ${ }^{14} \mathrm{C}$ to the associated $\mathrm{F} 1 \mathrm{stem}$ (Tab. IV), indicates that sprout shoots were still actively growing, i.e., leaf maturation and stem diameter, despite their visible 1-Lag status. It would be interesting to note if $\mathrm{F} 1$ leaves were acquiring enough carbon to meet the demands of the leaves and stem at this developmental stage. Under known source-sink relationships the answer would be yes since $>40 \%$ of fixed ${ }^{14} \mathrm{C}$ for sprouts in reduced light was exported to the roots (Tab. IV). What is unknown is if part of the ${ }^{14} \mathrm{C}$ in stems was retranslocated from the roots along with unlabeled carbon to support growth in sprout shoots even at 1-Lag.

We demonstrate that source-sink relationships in oak sprouts differ from seedlings. Specifically, sprout shoot growth is still occurring at 1-Lag, based on ${ }^{14} \mathrm{C}$ distribution and export patterns. Further, carbon stored in roots is being used by both leaves and roots (Lockhart et al., 2003). Carbon fixed by source leaves is utilized by both the shoot and root at the same time unlabeled carbon from the root is utilized. ${ }^{14} \mathrm{C}$ fixed by source leaves and translocated to roots is compartmentalized, possibly to growing root tips, while other root carbon sources are utilized by the sprout shoot. Evidence for this compartmentalization lies in the low levels of ${ }^{14} \mathrm{C}$ found in the leaves and stems of unlabeled sprouts $(<1 \%)$. Sprouts in full light, unlike those in shade, behaved similar to seedlings, probably in response to greater water stress. Undoubtably, much work remains in comparative carbon allocation between oak seedlings and sprouts, and the influence of roots in early sprout shoot growth and development.

Unlabeled sprout tissues, as well as branch tissues on seedlings, were weak sinks for carbon exported from source leaves. Slight accumulations of ${ }^{14} \mathrm{C}$ in these tissues probably reflects retransport of ${ }^{14} \mathrm{C}$-assimilates from root tissues rather than direct transport from source leaves (Dickson et al., 1990). Isebrands and Nelson (1983) also found low levels of ${ }^{14} \mathrm{C}$ in unlabeled branch tissues in Populus clones and, therefore, were not "parasitic" on the rest of the plant.

Results from the present research indicate a need to better understand oak sprout morphological development as it relates to ecophysiology. A morphological index, similar to the Quercus Morphological Index developed for northern red oak seedlings (Hanson et al., 1986), is needed to quantify patterns of oak sprout development. Field observations and literature indicate that oak sprouts display a similar pattern of recurrent flushing as seedlings (Borchert, 1975; Reich et al., 1980; Tworkoski et al., 1990), but the timing of flushing and allometric relationships appear different due to the root resources initially available to sprouts. An oak sprout morphological index can then be used to relate physiological processes and environmental conditions to specific stages of sprout ontogeny. A better understanding of sprout ecophsyiology and growth will help forest resource managers overcome oak regeneration failures and improve the sustainability of oak forests.
Acknowledgements: This research was supported by the U.S. Forest Service Southern Research Station, Center for Bottomlands Hardwoods Research and Department of Forestry, Mississippi State University. The authors thank Dr. R.F. Kellogg, Department of Biochemistry, Mississippi State University for laboratory guidance. We also thank Dr. Lisa Samuelson and Dr. Callie Jo Schweitzer for providing constructive comments to earlier versions of this manuscript. The authors would like to acknowledge the contributions that the late Dr. Patricia Tomlinson made in teaching us the ${ }^{14} \mathrm{C}$ labeling techniques during her tenure with the US Forest Service North Central Research Station.

\section{REFERENCES}

Abrams M.D., 1990. Adaptations and responses to drought in Quercus species of North America. Tree Physiol. 7: 227-238.

Beon M. and Bartsch N., 2003. Early seedling growth of pine (Pinus densiflora) and oaks (Quercus serrata, Q. mongolica, Q. variabilis) in response to light intensity and soil moisture. Plant Ecol. 167: 97105.

Blake T.J. and Tschaplinski T.J., 1986. Role of water relations and photosynthesis in the release of buds from apical dominance and the early reinvigoration of decapitated poplars. Physiol. Plant. 68: 287-293.

Bond W.J. and Midgley J.J., 2001. Ecology of sprouting in woody plants: the persistence niche. Trends Ecol. Evol. 16: 45-51.

Borchert R., 1975. Endogenous shoot growth rhythms and indeterminate shoot growth in oak. Physiol. Plant. 35: 152-157.

Bourdeau P., 1954. Oak seedling ecology determining segregation of species in Piedmont oak-hickory forests. Ecol. Monogr. 24: 297-320.

Cecich R.A., 1993. Flowering and oak regeneration. In: Loftis D.L. and C.E. McGee (Eds.), Oak Regeneration: Serious Problems Practical Recommendations, USDA For. Serv. Gen. Tech. Rep. SE84, pp. 79-95.

Chaar H., Colin F., and Collet C., 1997. Effects of environmental factors on the shoot development of Quercus petraea seedlings. A methodological approach. For. Ecol. Manage. 97: 119-131.

Collet C. and Frochot H., 1996. Effects of interspecific competition on periodic shoot elongation in oak seedlings. Can. J. For. Res. 26: 19341942.

Collet C., Ningre F., and Frochot H., 1998. Modifying the microclimate around young oaks through vegetation manipulation: effects on seedling growth and branching. For. Ecol. Manage. 110: 249-262.

Cowan I.R., 1994. As to the mode of action of guard cells in dry air. In: Schulze, E.D. and M.M. Caldwell (Eds.), Ecophysiology of Photosynthesis, Springer-Verlag, New York, pp. 205-229.

Crow T.R., 1988. Reproductive mode and mechanism for selfreplacement of northern red oak (Quercus rubra) - a review. For. Sci. 34: 19-40.

Dickson R.E., Isebrands J.G., and Tomlinson P.T., 1990. Distribution and metabolism of current photosynthate by single-flush northern red oak seedlings. Tree Physiol. 7: 65-77.

Dickson R.E., Tomlinson P.T., and Isebrands J.G., 2000a. Allocation of current photosynthates and changes in tissue dry weight within northern red oak seedlings: individual leaf and flush carbon contribution during episodic growth. Can. J. For. Res. 30: 1296-1307.

Dickson R.E., Tomlinson P.T., and Isebrands. J.G., 2000b. Partitioning of current photosynthate to different chemical fractions in leaves, stems, and roots of northern red oak seedlings during episodic growth. Can. J. For. Res. 30: 1308-1317.

Fitter A.H. and Hay R.K.M., 1987. Environmental physiology of plants. Second Ed., Academic Press, London, 423 p. 
Gardiner E.S. and J.D. Hodges. 1998. Growth and biomass distribution of cherrybark oak (Quercus pagoda Raf.) seedlings as influenced by light availability. For. Ecol. Manage. 108: 127-134.

Gardiner E.S., Russell D.R., Oliver M., and Dorris L.C. Jr, 2002. Bottomland hardwood afforestation: state of the art. In: Holland M.M., Warren M.L., and Stanturf J.A., (Eds.), Proc. Conference on Sustainability of Wetlands and Water Resources: How Well Can Riverine Wetlands Continue to Support Society into the 21st Century? USDA For. Serv. Gen. Tech. Rep. SRS-50, pp. 75-86.

Geiger D.R., 1987. Understanding interactions of source and sink regions of plants. Plant Physiol. Biochem. 25: 659-666.

Gottschalk K.W., 1994. Shade, leaf growth and crown development of Quercus rubra, Quercus velutina, Prunus serotina and Acer rubrum seedlings. Tree Physiol. 14: 735-749.

Hanson P.J., Dickson R.E., Isebrands J.G., Crow T.R., and Dixon R.K., 1986. A morphological index of Quercus seedling ontogeny for use in studies on physiology and growth. Tree Physiol. 2: 273-281.

Hodges J.D., 1967. Patterns of photosynthesis under natural environmental conditions. Ecol. 48: 234-242.

Isebrands J.G. and Nelson N.D., 1983. Distribution of $\left[{ }^{14} \mathrm{C}\right]$-labeled photosynthates within intensively cultured Populus cones during the establishment year. Physiol. Plant. 59: 9-18.

Isebrands J.G. and Dickson R.E., 1991. Measuring carbohydrate production and distribution: radiotracer techniques and applications. In: Lassoie J.P., and Hinckley T.M., (Eds.), Techniques and Approaches in Forest Tree Ecophysiology, CRC Press, Boca Raton, FL, pp. 358385 .

Jenkins M.W., and Chambers J.L., 1989. Understory light levels in mature hardwood stands after partial overstory removal. For. Ecol. Manage. 26: $247-256$

Johnson P.S., Shifley S.R., and Rogers R., 2002. The ecology and silviculture of oaks, CABI Pub., Oxon, UK, 503 p.

Kammesheidt L., 1998. The role of tree sprouts in the restoration of stand structure and species diversity in tropical moist forest after slash-andburn agriculture in Eastern Paraguay. Plant Ecol. 139: 155-165.

Kolb T.E., Steiner K.C., McCormick L.H., and Bowersox T.W., 1990. Growth response of northern red-oak and yellow-poplar seedlings to light, soil moisture and nutrients in relation to ecological strategy. For. Ecol. Manag. 38: 65-78.

Kruger E.L. and Reich P.B., 1993a. Coppicing alters ecophysiology of Quercus rubra saplings in Wisconsin forest openings. Physiol. Plant. 89: 741-750.

Kruger E.L. and Reich P.B., 1993b. Coppicing affects growth, root:shoot relations and ecophysiology of potted Quercus rubra seedlings. Physiol. Plant. 89: 751-760.
Lockhart B.R., Hodges J.D., Gardiner E.S., and Ezell A.W., 2003. Photosynthate distribution patterns in cherrybark oak seedling sprouts. Tree Physiol. 23: 1137-1146.

Lorimer C.G., 1993. Causes of the oak regeneration problem. In: Loftis D.L. and McGee C.E., (Eds.), Oak Regeneration: Serious Problems Practical Recommendations, USDA For. Serv. Gen. Tech. Rep. SE84, pp. 14-39.

Peterson R.G., 1985. Design and analysis of experiments, Marcel Dekker, Inc., New York, 429 p.

Reich P.B., Teskey R.O., Johnson P.S. and Hinckley T.M., 1980. Periodic root and shoot growth in oak. For. Sci. 26: 590-598.

Sander I.V., 1971. Height growth of new oak sprouts depends on size of advance reproduction. J. For. 69: 809-811.

Sander I.V., 1972. Size of oak advance reproduction: key to growth following harvest cutting. USDA For. Serv. Res. Pap. NC-79, 6 p.

SAS, 1985. SAS/STAT ${ }^{\mathrm{TM}}$ guide for personal computers, version 6 ed, SAS Institute, Cary, NC, 378 p.

Taylor J.S., Blake T.J., and Pharis R.P., 1982. The role of plant hormones and carbohydrates in the growth and survival of coppiced Eucalyptus seedlings. Physiol. Plant. 55: 421-430.

Tschaplinski T.J. and Blake T.J., 1989a. Photosynthetic reinvigoration of leaves following shoot decapitation and accelerated growth of coppice shoots. Physiol. Plant. 75: 157-165.

Tschaplinski T.J. and Blake T.J., 1989b. The role of sink demand in carbon partitioning and photosynthetic reinvigoration following shoot decapitation. Physiol. Plant. 75: 166-173.

Turgeon R., 1989. The sink-source transition in leaves. Ann. Rev. Plant Physiol. Mol. Biol. 40: 119-138.

Tworkoski T.J., Ross M.S., and Hopper G.M., 1990. Analysis of chestnut and scarlet oak stump sprout growth. Can. J. For. Res. 20: 112-116.

van Hees A.F.M., 1997. Growth and morphology of pedunculate oak (Quercus robur L.) and beech (Fagus sylvatica L.) seedlings in relation to shading and drought. Ann. Sci. For. 54: 9-18.

Watt R.F., 1979. The need for adequate regeneration in oak stands. In: Holt, H.A. and B.C. Fischer (Eds.), Proc. Regenerating Oaks in Upland Hardwood Forests, Purdue Univ., Lafayette, IN, pp. 11-17.

Welander N.T. and Ottosson B., 1998. The influence of shading on growth and morphology in seedlings of Quercus robur L. and Fagus sylvatica L. For. Ecol. Manage. 107: 117-126.

Ziegenhagen B. and Kausch W., 1995. Productivity of young shaded oaks (Quercus robur L.) as corresponding to shoot morphology and leaf anatomy. For. Ecol. Manage. 72:97-108. 